\title{
WOMEN AND THE WORD IN THE EARLIER MIDDLE AGES
}

\author{
by JANET L. NELSON
}

I

$\mathrm{T}$ is a characteristic merit of Richard Southern-recently voted the historians' historian in The Observer-that as long ago as 1970, in Western Society and the Church, he devoted some luminous pages to 'the influence of women in religious life.' ${ }^{1}$ Though these pages nestle in a chapter called 'Fringe orders and anti-orders', twenty years ago such labels were not pejorative. Southern made women emblematic of what could be called a pendulum-swing theory of medieval religious history. First came a primitive, earlier medieval age of improvization and individual effort, of spiritual warriors and local initiatives; the central medieval period saw 'a drive towards increasingly well-defined and universal forms of organization' in an age of hierarchy and order; then, in the fourteenth and fifteenth centuries, back swung the pendulum towards complexity and confusion, individual experiment, and 'small, humble, shadowy organizations'.

Where do the women fit in? Well, the female counterparts to the spiritual warriors were 'the masterful and formidable ladies' who ran early medieval convents in 'splendid independence'. But 'as society became better-organized and ecclesiastically more right-minded [this is Southern at his tongue-in-cheekiest], the necessity for male dominance began to assert itself. The heading of Southern's section on women in the twelfth and thirteenth centuries is 'Decline'. In a general atmosphere of increasing misogyny, new opportunities were more than counterbalanced by increasingly frequent frustrations. At the close of the twelfth century - that century in which Michelet once located la restauration de la femme $^{3}$ - the monastic orders closed their doors to women, and subjected those women who had already sneaked in to ever stricter male supervision. Or tried to: Southern tells, with relish, the story of the Cistercian

1 R. W. Southern, Westerm Society and the Church in the Middle Ages (Harmondsworth, 1970), pp. 309-18. The phrases quoted below, and Southern's exposition of the three phases in the history of medieval Christendom, are at pp. 300-1. For other historians' appreciations of Southern, see The Observer Colour Supplement, 9 (July 1989).

2 Southern, Western Society, p. 3 Io.

${ }^{3}$ Michelet's view is examined, and rebutted, by D. logna-Prat, ' $\mathrm{La}$ femme dans la perspective pénitentielle des ermites du Bas-Maine (fin XIme début XIlme siècle)', Revue d'Histoire de la Spiritualité, 53 (1977), pp. 47-64. 
nuns of Parc aux Dames. When, in 1243 , new disciplinary legislation subjecting them to the authority of abbots was read out to them, 'they shouted and stamped and walked out of the chapter house'. ${ }^{4}$ Again, like those earlier medieval nuns, these were noble ladies, used to command. But they were, still, 'on the fringe of an organization'. So much for the influence of women.

With the later Middle Ages, Southern's focus shifts away from women: which is curious, since we are now in those household setrings, where devout Netherlandish laymen lived out lives of 'mild usefulness ... and total absorption in domestic affairs'. Southern does not pursue the patriarchal in domestic religion: his note of mild distaste is for its domesticity as such. ${ }^{5}$ What Southern's periodization amounts to for women, then, is:

(I) In an earlier medieval Christendom dominated by local aristocracies, a few noble women appeared among local dominators.

(2) In the central medieval period male-dominated organization reduced even this amount of female activity.

(3) In the later Middle Ages, the religious activity of men was not only relocalized, but domesticized. 'Small, humble, shadowy organizations' put women effectively in the shade.

All three phases have something in common: women's religious participation, however interesting, or affecting, seems in the end rather marginal: a fringe activity.

Since 1970, the thrust of historiography, mainly in the U.S.A., has moved the fringe into the centre. Existing periodizations have been labelled: 'men only'. 'Women's participation in medieval religious life is nowadays taken much more seriously than even the prescient Southern can have expected. The earlier Middle Ages are depicted in terms of, first, a Merovingian heyday for both women's property rights and female sanctity, followed by, in the Carolingian period, a partial relegation, offset by very substantial improvements in women's legal status, and thereafter, a kind of 'feminist revival' from the later ninth century to the Gregorian Reform.? In the central and later Middle Ages

- Southern, Western Society, p. 317.

${ }^{5}$ Ibid., p. 356.

- J. Kelly, Women, History and Theory (Chicago, 1984), pp. 2-4, 19-20.

7 S. Wemple, Women in Frankish Society: Marriage and the Cloister, 500-900 (Philadelphia, 1981), pp. 127-88; M. Skinner, 'Benedictine life for women in Central France, 850-1 100: a feminist revival', in J. A Nichols and L. T. Shank, eds, Medieval Religious Women, 2 vols (Kalamazoo, 1984 and 1987), 1, Distant Echoes, pp. 87-1 I 3. See further J. T. Schulenburg, "Strict active enclosure and its effects on the female monastic experience (500-1 I00)', in Nichols and 


\section{Women and the Word}

are found new varieties, social and religious, of women's empowerment. $^{8}$

Compare Southern's account of the wordy nuns of Parc aux Dames, for instance, with Sharon Farmer's analysis of certain recommendations found in confessors' manuals from $c$. I 200 onwards: the wife was urged to assume responsibility for her husband's spiritual well-being, to exploit her way with words to insinuate into her husband's ear, even in bed, his religious obligations. This was to make women's religious activity more than mildly useful: it constituted a privatization of pastoral care. ${ }^{9}$ What role could be more appropriate for women, placed as they were conveniently in the home? Call to mind some later medieval depictions of woman: of the Virgin Mary-consumer, in the solitude of her chamber, in private devotion, of the written word; devoted mother, somerimes also devoted daughter. The domestic detail puts woman in her place. But it also defines her space. Moreover, the woman in question may look like a peasant or a bourgeoise: can we infer a democratization, an extension to all women of the role hitherto played by noble ladies in fostering their spouses' virtue? This may be more than just a trick of the evidential light. There are more domestic interiors in later medieval art. ${ }^{10}$ But it has been argued (I need only cite C. W. Bynum's exceptionally interesting recent book) that in the later Middle Ages women, poor servants as well as great ladies, took an active part in designing their own religious roles, not rejecting, but appropriating and exploiting, the gender stereotype that underpinned them. ${ }^{11}$

I want to review this morning some of the evidence for the religious activity of women in the earlier Middle Ages, and especially (though not exclusively) during the Carolingian period. For the immediately preceding

Shank, I, Pp. SI-86; idem, 'Female sanctity: public and private roles, ca. $500-1100$ ', in M. Erler and M. Kowaleski, eds, Women and Power in the Middle Ages (Athens, Georgia, 1988), Pp. 102-25; idem, 'Women's monastic communities, 500-1 100: patterns of expansion and decline', Signs, I 4 (1989), Pp. 26 I -92; D. Herlihy, 'Did women have a renaissance?: a reconsideration', Medievalia et Humanistica, I 3 (1985), pp. I-22. For criticisms of the general approach of much recent American historiography, see the review of Nichols and Shank by J. McClure in EHR, I02 (1988), p. 1005.

- See Erler and Kowaleski, eds, Women and Power.

9. Farmer, 'Persuasive voicess: clerical images of medieval wives', Speculum, 61 (1986), Pp. $517-43$.

10 See, for instance, S. G. Bell, 'Medieval women book owners', Signs, 7 (1982), pp. 742-68 (reprinted in Erler and Kowaleski, eds, Women and Power, pp. 1 49-87); L. Dresen-Coenders, ed., Saints and She-Devils. Images of Women in the Fifteenth and Sixteenth Centuries (London, 1987).

"C. W. Bynum, Holy Feast and Holy Fast: the Religious Significance of Food to Medieval Women (Berkeley, 1987). 
Merovingian centuries, a good deal of recent work exists-though I may already have let slip my reservations about some of the patterns allegedly to be inferred from the available hagiographic and conciliar texts. For the tenth century, Karl Leyser's exemplary account of Saxon convents has demonstrated how research on women can be integrated into the wider history of a particular society to illuminate its political workings as well as its religious priorities. ${ }^{12}$ But there is a risk of some of his findings being generalized by others in misleading ways: from a Frankish perspective, after all, Saxony was different-not to say peculiar!13

A pendulum can swing within a solidly patriarchal clock. A sense of déjà $v u$ is all too familiar to those who seek to recover, nearly always at one remove, the experience of women in the past. To find evidence for 'emancipation' or 'empowerment', determined feminist historians (and not all of them would want to abandon the concept of patriarchy ${ }^{14}$ ) have ploughed their way through a mass of biological constraints, entrenched gender relations of oppression and repression, clods of solid misogyny. Even in the field of Ecclesiastical History, it has proved possible to historicize gender. But the earlier medieval evidence, varied and extensive as it is, is also more problematic than some recent historians have implied. Southern may have been right all along about the marginal quality of women's involvement in the life of the Church, and the ambiguity of clerical attitudes to that involvement. My hope is to supply a more specific anchorage for those general conclusions, by showing how both the ways in which women were represented, and the ways women acted, were required and permitted by the conditions of the earlier medieval West.

In choosing to speak about 'Women and the Word', I intend to go with the grain of the evidence. I've also been deliberately ambiguous. 'Word' is used in Christian discourse to mean an aspect of the Deity, and to refer to the sacred text as divine utterance. My concern is with women's access to both, and how far such access was gender-conditioned. But, since History is logically prior to Ecclesiastical History, I'll begin by identifying, in a general way, the relationship thought to exist in the earlier Middle Ages between women and the word with a small 'w'. Women, statistically no doubt then as now a majority of the faithful, weren't always a silent

12 K. Leyser, Rule and Conflict in an Early Medieval Society: Ottonian Saxony (London, 1979), pp. 63-73.

13 The particularities of Leyser's account of tenth-century Saxony are not sufficiently allowed for by Schulenburg, 'Female sanctity'. See also the remarks of M. Lauwers, 'Sainteté royale et sainteté féminine dans l'Occident médiéval', RHE, 83 (1988), pp. 58-69.

14 J. M. Bennett, 'Feminism and History', Gender and History, I (1989), pp. $251-72$. 
majority. After considering briefly some ways in which women did and did not use words, and ways in which the word spoken or written by women was perceived as different from, and/or inherently inferior to, the discourse of men, I shall go on to consider women's access to the Word, meaning the revealed truths of the Christian religion, and women's active roles in appropriating the Word, and spreading it both through written and oral media.

First, then, I want to underline the point that the evidence is hard to interpret; and that is more than a truism. It is not just that there is relatively little of it, and what there is is mostly prescriptive: all early medievalists confront those problems. But the special scarcity of evidence on earlier medieval women has led to hasty and over-enthusiastic use of some actually rather uncertain bits. Take canon I9 of the Council of Nantes of 895: quoted by Suzanne Wemple a decade ago, and since then rehearsed by several other women's historians, canon 19 is on the way to becoming a canonical text:

Since the Apostle says: 'Let women be silent in church, for it is not permitted for them to speak' (I Cor. xiv), it seems astonishing that certain mulierculae ceaselessly come to public assemblies and there disturb, rather than dispose, the affairs of the realm and business of state, since it is unfitting and reprehensible even among barbarian peoples that women should discuss the affairs of men, and that those female persons who should be sitting in women's quarters discussing weaving and textile work should usurp for themselves the authority of senators in a public assembly, as if they were sitting in court. This shameful behaviour ought to be imputed to the men who encourage them rather than to the women themselves. ${ }^{15}$

Does this text show, as recently alleged, the clamp-down of Carolingian reformers on women's exercise of leadership in the Church ${ }^{16}$ Hardly. Mulierculae don't sound like leaders; the canon's heading is: 'Nuns should not attend the palace'. ${ }^{17}$ These women, anyway, have fautores (protectors,

${ }^{15}$ Mansi, 18, cols 171-2. See Wemple, Women in Frankish Society, pp. I05-6; J. L. Nelson, 'Dispute settlement in Carolingian West Francia', in W. Davies and P. Fouracre, eds, The Settlement of Disputes in Early Medieval Europe (Cambridge 1986), pp. 45-64, at p. 58, n. 49; J. A. McNamara and S. Wemple, 'The power of women through the family', in Erler and Kowaleski, eds, Women and Power, pp. 83-101, at p. 93; Schulenburg, 'Female sanctity', p. 116.

16 Schulenburg, ibid.

${ }^{17}$ Regino, De ecclesiasticis disciplinis, ii, cap. 175, PL I 32, cols 317-18: 'Ne sancrimoniales palatium et publicos conventus adeant'. Muliercula is used in a pejorative sense, regardless of class, in Jerome, Lettres, ed. J. Labourt (Paris, 1949), pp. 124, 140. (J. W. Drijvers kindly 
patrons)-who are men. But canon 19 presents more worrying problems: its official status is doubtful, and its alleged date is, in fact, that of another council (Tribur), whose canons are given on the same page of Mansi's Concilia. There was no council of Nantes in 895. Regino of Prüm is the earliest source for this text (Burchard got it from him): it may be Merovingian, and it could be a forgery.$^{18}$ Regino may have included it because he had had to contend with some awkward female influence at the Lotharingian court. ${ }^{19}$ This canon is, in any event, not one on which generalizations can be built without further spadework.

Interpreting early medieval texts is no simple matter. It's as true, for instance, of the Vitae of male saints as of female ones, that a typological reading is of ten required. But a gender-specific problem does arise, and not just because the authors of nearly all Vitae are men. Historians can learn something from the anthropologist's idea that women are 'good to think' ${ }^{20}$ That is to say, women have diverse, and opposed, meanings inscribed on them, and lend themselves to such multiple interpretations in ways that men do not. It's no coincidence that favourite subjects of Christian monastic spirituality should be the bride/soul/Church of the Song of Songs and the composite image of Mary, virgin-mother, sinner/saved. It hardly needs adding, but perhaps is worth adding because historians and anthropologists seldom say so explicitly (and the French on can allow a

supplied these references.) In early medieval Latin, however, the term generally seems to imply lowly social status.

18 The date is given in Mansi, 18, at cols $165-6$. J. Sirmond's note at the bottom of col. 172 considers the dating problem. I am grateful to Julia Smith for help and correction on this point. See O. Pontal, Die Synoden der Merowingerreich (Paderborn, 1986), pp. 202-3, for references on the disputed date, and authenticity, of the alleged canons of Nantes.

19 Regino, Chronicon, sa 900, ed. F. Kurze, MGH. SRG (Hanover, 1890), p. 148, mentions conflict between King Zwentibold and his magnates, 'quia cum mulieribus et ignobilioribus regni negotia disponens, honestiores ... deiciebat'.

20 P. Brown, The Body and Society (California, 1989), p. 153, draws explicitly on C. Levi-Strauss (and the French 'bonnes à penser' is of course ambiguous: 'good to think'/goods to think'). But note the latter's defensive tone in The Elementary Structures of Kinship (London, 1968), p. 496: 'Woman could never become just a sign and nothing more, since even in a man's world she is still a person... In contrast to words which have wholly become signs, woman has remained at once a sign and a value'; and idem, Structural Anthropology (Harmondsworth, 1977), P. 6I: 'It may be disturbing to some to have women conceived as mere parts of a meaningful system. However, one should keep in mind that ... words do not speak, while women do; as producers of signs, women can never be reduced to the status of symbols or tokens'. Cf. S. J. Tambiah, 'Animals are good to think and good to prohibit', Ethnology, 8 (1969), pp. 424-59. For alternative views to Levi-Strauss's, see S. B. Ortner, 'Is female to male as nature is to culture?' in M. Z. Rosaldo and L. Lamphere, eds, Woman, Culture and Society (Stanford, 1974), pp. 67-87, and M. Z. Rosaldo. 'The use and abuse of anthropology', Signs, S (1980), pp. 389-417. 


\section{Women and the Word}

French savant to evade the issue-or the issue to elude him), that such recorded thinking and interpreting has been performed, initially exclusively, and thereafter overwhelmingly, by men. Women themselves seem passive, working within a received tradition that has been man-made; and the thinking of any of them is, of course, almost wholly unrecorded.

This compounds the difficulty of reaching back beyond the texts to changes in historical reality or perceptions of that reality. For instance, in a recent, thought-provoking study of early medieval missionaries, a passage in the Sermon on the veneration of Mary Magdalene attributed to Odo of Cluny is taken to mean that a female apostolate was at least conceivable, and cautiously approved, by the doyen of tenth-century reformed monasticism. ${ }^{21}$ Well, the attribution to Odo sounds implausible (not least, given his well-known view of woman as a saccus stercoris-a bag of excrement ${ }^{22}$ ) and is almost certainly false. But to ask how such a text should be read is also to ask (as Dominique Iogna-Prat has, in effect, recently done): for whom was it good to think? Its audience consisted of male contemplatives: the significance of Mary Magdalene's apostolate here had nothing to do with pastoral care. Mary was the type of monastic spirituality, the inactive rather than the active life. For the author of the Sermon, the crucial point was what Mary professed in her anointing of Christ's head (Mark I4.3-9): through a gesture, without a word, she professed silently, internally, her uncleanness and her repentence. She sat at Christ's feet (Luke 10.39): she withdrew from the world for communion with God. ${ }^{23}$ The interpretation was not specifically Cluniac. It linked the monastic traditions of Late Antiquity with those of the High Middle Ages. It was, strictly speaking, transcendental: beyond historyand, like virginity, beyond gender. But it was imposed on a female object. In much the same way, and likewise for a monastic audience, Notker the Stammerer 'thought' the Holy Women, not to praise 'the Perpetuas of this world', but to gauge the strengthening and cleansing power of God. ${ }^{24}$

21 F. Lifshitz, 'Les femmes missionnaires: l'exemple de la Gaule franque', RHE, 83 (1988), pp. 5-33.

22 Collationes, ii, cap. 9, PL I 3, col. 556: 'Nam si viderent homines hoc quod subtus pellem est ... mulieres videre nauserent ... Si quis enim considerent quae intra nares, et quae inter fauces, et quae intra ventrem lateant, sordes utique reperiet. Et si nec extremis digitis flegma vel stercus tangere patimur, quomodo ipsum stercoris saccum amplecti desideramus?'

${ }^{23}$ D. logna-Prat, "Bienheureuse polysémie". La Madeleine du Sermo in veneratione sanclae Mariae Magdalenae attribué à Odon de Cluny', in Marie Madeleine dans la Mystique, les Arts et les Lèttres= Actes du Colloque organisé par le Musée Pétrarque à Avignon, juillet 1988 (Paris, 1989), pp. $21-31$.

24 For the text, with an English translation, of Notker's poem, In natale sanctarum feminarum, see P. Godman, Poetry of the Carolingian Renaissance (London, 1985), Pp. 318-21. Against the reading of P. Dronke, The Medieval Lyric (London, 1968), pp. 41-4, Godman, pp. 65-7, argues 
In the classical cultural traditions that early medieval Christendom inherited, the relationship of women and word was certainly a major way in which gender was constructed. It was also ambiguous. Compare the following:

Standards of good behaviour are different for men and women:... a woman would seem a chatterbox if she were no more reticent than a well-behaved man. (Aristotle, Politics, III.5.)

The Germans believe that there resides in women an element of holiness and prophecy (sanctum aliquid et providum), and so they do not scorn to ask their advice or lightly disregard their replies. (Tacitus, Germania , cap. 8.)

Aristotle's aside revealingly used an assumption about gender as an analogy for the difference between ruler and ruled (though the analogy was limited: while a man, as a citizen, could 'rule and be ruled by turns', the gender-difference was absolute). Tacitus, writing not ethnology but ethics for Romans, was making the point that female hostages ought to be accepted from Germans, contrary to Roman practice, and his invocation of religious to impute political standing was a characteristic piece of elision: effective, of course, precisely because the Romans themselves were familiar with the idea that women could function as mouthpieces of 'a holy something'. Yet of Germans' attitudes to their women, Tacitus took care to add: 'they never treated them with adulation, as goddesses'.

Early medieval readers did not have direct access to Aristotle's Politics, or Tacitus's Germania ; but they had the Bible, with all its rich ambiguities. Scripture offered examples of a holy something in the words of women: of Judith's song of triumph; Esther's good counsel; Mary's Magnificat. In the Middle Ages, however, women were more often reminded of the following:

Let the woman learn in silence with all subjection. But I suffer not a woman to teach, nor to usurp authority over the man, but to be in silence. (I Timothy 2.I 2-I5.)

How did literate women in the early Middle Ages situate themselves vis-à-vis such valuations? Those few female writers whose works we have

that Notker wrote this sequence in praise of 'Everyman'. My view is that Notker was using various female types, and the liturgical setting of the feasts of fernale saints and martyrs, "to think' themes relevant to his fellow monks. 
seem at first reading strong on womanly weakness, hence to have entirely internalized existing stereotypes. In the ninth century, the Frankish aristocrat Dhuoda called herself 'lukewarm, lazy, and feeble'. She held up a number of Old Testament patriarchs for her son to follow; but never seems to have thought of Esther or Judith as role-models for herself. ${ }^{25}$ In the tenth century, the noble nun Hrotsvitha of Gandersheim hoped the shortcomings of her Deeds of Otto would be more readily forgiven because she was 'weaker in sex, lesser in knowledge' ${ }^{26}$ These are routine captationes benevolentiae - pleas for the reader's tolerance; but, as Natalie Z. Davis observed, the topoi of humility have a special bite in the mouth of a woman. ${ }^{27}$ In what these women went on to say, and do, confidence resounded alongside consciousness of a frailty human rather than feminine ${ }^{28}$ Hrotsvitha punned on her own name: its two elements meant 'large' and 'noise', and so she could introduce herself as ego clamor validus. ${ }^{29}$ As for Dhuoda, she termed herself 'inter dignas vivens indigne': that is, while acknowledging her own 'unworthy living', she asserted the existence of other dignae - worthy women. ${ }^{30}$ Furthermore, both Dhuoda and Hrotsvitha used the written word with self-conscious prowess: each wrote, as Dhuoda put it, ex nomine meo-in my own right. ${ }^{31}$ Neither apologized for garrulousness or guile.

The topos of the chattering woman, the scold, speaking out of turn and out of control, is so familiar to us from the later Middle Ages, and more recently, that it's with some surprise that I've registered its near-total absence from earlier medieval texts. ${ }^{32}$ What does this mean? Women's

25 Dhuoda, Manuel pour mon fils, ed. P. Riché (Paris, I975), ii, 3, lines I 8-19, p. I 26, makes no use whatsoever of any positive feminine stereotypes, biblical or otherwise.

26 Gesta Ottonis, in Hrotsvithae Opera, ed. P. von Winterfeld, MGH. SRG (Berlin, I902), p. 202. See P. Dronke, Women Writers of the Middle Ages (Cambridge, 1984), pp. 55-83, at pp. 76-7; J. L. Nelson, 'Perceptions du pouvoir chez les historiennes du Haut Moyen Age', in M. Rouche, ed., Les Femmes au Moyen Age (Maubeuge, 1990), pp. 77-87.

27 'Gender and genre: women as historical writers, I 400-I820', in P. Labalme, ed., Beyond their Sex: Learned Women of the European Past (New York, 1980), pp. I53-82, at p. I65.

29 P. Riché, in the Introduction to his edition of Dhuoda's Manuel, pp. 28-9.

29 Hrotsvitha, Opera, p. 106. See Dronke, Women Writers, pp. 69-70.

30 Dhuoda, Manuel, p. 8o, line 6.

31 Ibid., p. 72. Cf. p. I 14 , line I 5 , where Dhuoda calls herself her son's ortatrix.

32 For the scold in later medieval literature, see R. H. Bloch, 'Medieval misogyny', Representations, 20 (1987), pp. 1-27. Rare early medieval imputations of excessive wordiness to women in general may be found in the Sermons of Caesarius of Arles, ed. G. Morin, CChr.SL, 103 (1953). pp. 243, 323. Gregory the Great, Dialogues, II, 23, 2-5, pp. 206-8, and IV, 53, I-2, p. 178, ed. A. de Vogüé, SC, 260, 26s (Paris, 1979, 1980), pp. 206-8, 178, tells stories of wordy women, but draws lessons that are not gender-specific. Aimoin, Historia translationis $S$. Vincentii ex Hispania in Castrense Galliae monasterium, $P L 126$, cols $1011-12$, describes a 
voices were indeed to be heard in certain areas. A Carolingian capitulary forbids the writing, or sending, of winileodas at convents: the implication is that women are particularly skilled at writing in this genre (whatever it was: love-songs? heroic verse? $)^{33}$ Another capitulary specifies penalties not only for men who refuse the king's new coinage, but also for women who do so-quia et feminae barcaniare solent, which a modern historian translates as: 'because women are in the habit of arguing', though what the text says is 'women too are accustomed to engage in trading, ${ }^{34}$

But this was no Golden Age for the female voice. Women's legal disabilities in this period were universal. True, they were subject to modification in practice: from Anglo-Saxon England and from Francia come rare cases of women speaking up in lawcourts to defend their own property rights. But it was a still rarer case in which no kinsman or church stood to gain from the woman's outspokenness. ${ }^{35}$ Only when women were accused of gender-specific crime, might the words of other women be accorded the authority of experts: a court consisting of the wives of imperial counsellors was mustered to pronounce the death-sentence for

monk and a bishop fighting muliebriter for the saint's relics, implying general lack of proper control rather than wordiness.

${ }^{33}$ MGH. Cap, I, ed. A. Boretius (Hanover, 1883), no 23, cap. 19. p. 63. See Nelson, 'Perceptions du pouvoir, p. 78.

34 MGH. Cap, II, no 27I, p. 302. For a modern historian's misrendering, see R. Doehaerdt, The Early Middle Ages in the West, Economy and Society (Amsterdam and New York, 1978), p. 228. CE. P. Grierson, 'The Gratia Dei Rex coinage of Charles the Bald', in M. T. Gibson and J. L. Nelson, eds, Charles ihe Bald: Court and Kingdom, 2nd edn revd (London, 1990), pp. 52-64, at p. 6.: 'since women in particular were accustomed to bargaining before making purchases".

35 See below, p. 75. For the persisting interests of men in claims vested in female kin or transmitted through female benefactors, see my 'Commentary', in W. Affeldt, ed., Frauen in Spätantike und Friilmmittelalter (Sigmaringen, 1990). Since such interests so of ten lie behind affirmarions of the rights of particular women in early medieval legal documents, it seems questionable to infer that women (even among the landholding classes) could 'dispose freely of their property' and enjoyed 'economic independence': so, McNamara and Wemple, 'The power of women through the family', p. 93, but without a critical re-examination of any of the evidence. I hope to deal with this subject elsewhere. Meanwhile, to forestall too-ready acceptance of the general proposition of women's 'independent' control of property, it is worth signalling E. Magnou-Nortier, 'Ombres féminines dans l'histoire de Languedoc aux Xème et Xlème siècles', Cahiers de civilisation médiévale ( 1990 , forthcoming) ('Même dans la haute aristocratie, les femmes donnent l'impression d'avoir été utilisées et absorbées par leurs lignages d'origine ou d'adoption. Leurs initiatives sont controlées; la part d'héritage dont elles disposent semble exigüe'); P. Stafford, 'Women in Domesday', in Medieval Women in Southern England = Reading Medieval Studies, is (Reading, 1989), pp. 75-94; and, from the perspective of a rather later period, when the practices of aristocrats and humbler folk can be compared, $D$. O. Hughes, 'From brideprice to dowry', Journal of Family History, 3 (1978), pp. 262-96, and L. Roper, The Holy Household, Women and Morals in Reformation Augsburg (Oxford, 1989), pp. 40-9. 


\section{Women and the Word}

witchcraft on a female opponent of a Carolingian emperor, while the testimony of many noble West Saxon women enabled Earl Godwin's wife to rebut her own son's allegation that his father was not Godwin. ${ }^{36}$

The normal legal incapacity of women in general did not precludeand for us, throws into sharp relief-some women's vociferous political activity. This very contradiction is gender-specific. There are no female witnesses in the charters of ninth-century eastern Brittany, yet the tirannissa Aourken, evidently influential in her own locality, was used as a spokesperson there by the Breton $d u x$ Salomon. ${ }^{37}$ Politics, in other words, or, more generally, class, could transcend gender. The women who hosted major diplomatic occasions, at Andelot in 587, Whitby in 664, Chelles in 804 , were royal women, praised for their influential words. ${ }^{38}$ The regiment of women was not condemned out of hand as monstrous in the early Middle Ages: regencies of queen-mothers were accepted in some (if not all) early medieval kingdoms, and exercised effectively too. On the other hand, a female regent was vulnerable to the charge flung at Brunhild by a recalcitrant duke: 'Leave our company, $O$ woman! Let it be enough for you to have held the realm under your husband: but now your son reigns, and his realm is kept safe by our protection, not yours! ${ }^{39}$ There was an obvious time-limit on the power of such regents. As for a queen regnant, no clear case can be found in the early medieval West, and Eirene's attempt to rule as basileus in the East after 796 exposed her regime to easy western charges of illegitimacy. If Eirene's proposal of marriage to Charlemagne revealed her own anxieties about Byzantine public opinion, a Carolingian propagandist hardly needed to spell it out that 'supreme authority in a woman's hands' was a contradiction in terms. ${ }^{40}$ The influence of strenuae matronae explains much in the rise of the Carolingians, as in Frankish politics generally, but only in select cases is it

36 Thegan, Vita Hludowici imperatoris, cap. 52, ed. G. Pertz, MGH. SS, 11, p. 60I; Hemingi Cartularium, ed. T. Hearne (Oxford, 1737), Pp. 275-6. (My thanks are due to Ann Williams for this reference.)

37 W. Davies, Small Worlds (London, 1988), p. 78.

${ }^{38}$ MGH. Cap, I, p. 12-14 (Brunhild); Bede, Hist. ecc., iii, cap. 25, Plummer, Bede, 1, p. 183 (Hild); Annales Mettenses Priores, sa 804, ed. B. Simson, MGH. SRG (Hanover, I905), p. 92 (Gisèle). The first two examples are well known; for the third, see below, pp. 64-5.

39 Gregory of Tours, Libri Historiarum, vi, cap. 4, ed. B. Krusch and W. Levison, MGH.SRM, I, i, and edn (Berlin, I937-51), p. 268.

40 Annales Laureshamenses, sa 801, ed. G. H. Pertz, MGH. SS, I, p. 38: the decision to crown Charlemagne was made 'quia iam tunc cessabat a parte Graecorum nomen imperatoris, et femineum imperium apud se abebant'. See J. Herrin, The Formation of Christendom (Princeton, 1987), pp. 454-7. 
acknowledged by Frankish annalists. ${ }^{41} \mathrm{~A}$ letter from Charlemagne to his wife, Fastrada, detailing a successful campaign, and asking her to organize the saying of thanksgiving litanies, shows that this queen was a valued counsellor with an audible public role. Yet the details here suggest the novelty of the liturgical arrangements, and Fastrada in the 790s became the scapegoat for political discontents in and around the royal family: an archetypical wicked queen. ${ }^{42}$

All this gives a context for reconsidering those 'masterful and formidable' abbesses whom Southern thought characteristic of the early medieval West. In fact, there were never many of them; and most were very closely associated with royal courts and royally-patronized convents. As great landowners, and hence granters-out of benefices, these abbesses could be called on to produce, and arm, troops for royal armies-and, on one occasion at least, were threatened with the same penalties as abbots, bishops, and counts, for non-compliance. ${ }^{43}$ But there is no evidence that abbesses ex officio were summoned to royal assemblies or took oaths of fidelity to royal lords. ${ }^{44}$ An abbess might be called magistra or consiliatrix, but such status had less to do with office than with person, specifically with individual closeness to a particular king. ${ }^{45}$ Charlemagne's sister, Abbess Gisèle of Chelles, who accompanied her brother to Rome in 800 , and sent word of his imperial coronation back to Francia, was hailed by Alcuin as femina verbipotens. I think he meant to comment on more than her learning. Chelles was chosen by Charlemagne to house not only his daughter Rotrud, but also a relic collection of truly imperial dimensions, and Gisèle was arguably one of her brother's key advisers in the decade

41 Annales Mettenses Priores, sa 693, p. 16. See further R. A. Gerberding, The Rise of the Carolingians and the Liber Historiae Francorum (Oxford, 1987), cap. 7 .

${ }^{42}$ MGH. Ep, IV, ed. E. Dümmler (Hanover, 1895), pp. 528-9. On liturgical innovations, see M. McCormick, Eternal Victory (Cambridge, 1986), pp. 352-3. For Fastrada's later reputation, see Annales Regni Francorum, revised version, sa 792, ed. F. Kurze, MGH. SRG (Hanover, 1895), p. 91 ; Einhard, Vita Karoli Magni, ed. G. Waitz, MGH. SRG (Hanover, 191 J), cap. 20, p. 26.

${ }^{43} M G H$. Cap II, no 218 , cap. 4, p. 96. Cf. $M G H$. Cap, I, no 74, cap. 1o, p. 167; MGH. Cap, II, no 274, cap. 1 3, p. 33 I; Annales de Saint Bertin, sa 869, ed. F. Grat et al. (Paris, I 964), p. 153.

44 Pace the implication of J. Verdon, 'Note sur le rôle economique des monastères féminins en France dans la seconde moitie du IXe et au debut du Xe siècle', Revue Mabillon, 98 (1975), pp. 329-43, at p. 332 with n. 40 . The letters of Archbishop Fulk of Rheims (not Hincmar) summarized in Flodoard, Historia Remensis Ecclesiae, IV, cap. 6, ed. J. Heller and G. Waitz, $M G H$. SS, XIII, pp. 568-9, refer to a particular dispute arising from a murderous attack on a priest. Abbess Hildegard is told to attend an episcopal court hearing (conventus). Nothing can be inferred about a general obligation of abbesses to attend assemblies in the wider, political sense.

15 Bede, Hist. ecc., iii, cap. 24, p. I79; Eddius Stephanus, Vita Wilfridi, ed. B. Colgrave (Cambridge, 1927), cap. 60, p. 128. 
around $800 .{ }^{46}$ Her case is a notable one-and notably neglected in modern historiography. But it is exceptional.

On Gisèle's rather older contemporary, Abbess Leoba of Bischofsheim, there's more information: according to her Life, itself written for a female patron 'in order that you might have something to imitate', 'Leoba ... though she hated the hurly-burly of the palace like a poisoned cup ...., was of ten summoned there by Charlemagne, who loaded her with gifts ... Queen Hildegard ... would have liked to have her always at her side so that she could benefit from her words and example... Princes loved her, magnates welcomed her, bishops embraced her. And because she was very learned in the Scriptures and generous in counsel, they discussed the word of life with her and often talked over ecclesiastical legislation'47

Leoba's case is an interesting one. For she does not quite fit the usual categories of earlier medieval female sanctity. Charles Plummer remarked à propos Queen Balthild's attainment of saintship: 'this is not conclusive as to her character, very curious people finding their way in those days into the ranks of the saints'. ${ }^{48}$ The 'curious people' were generally characterized by nobility or regality, and their local cults were products of a kind of noble or dynastic 'self-canonization' ${ }^{49}$ This could occasionally transcend gender, just as status and office could occasionally transcend person. But Leoba, for all her Königsnahe, and her kinship with Boniface, ${ }^{50}$ was not a saint of this kind. Nor is her Vita a mere compound of hagiographic topoi. On the contrary, its distinctive details lend it some claim to authenticity. Leoba's hagiographer goes out of his way to establish the credibility of his material: writing nearly fifty years after Leoba's death, in 779, he mentions as oral sources four nuns (all named) who had known Leoba, and one written source, the shorthand notes of a priest who had recorded what the nuns told him. ${ }^{51}$ The following vision-story rings as true as hagiography can (I know of no clear parallel):

One night Leoba saw a purple thread coming out of her mouth. It seemed to her that when she took hold of it with her hand and tried to pull it out that there was no end to it... When her hand was full of

46 See Nelson, 'Perceptions du pouvoir'.

17 Vita Leobae, ed. G. Waitz, MGH. SS, XV, pp. 1 18-31. The quotations here are from cap. 18 , p. 129 [my translation; cf. that of C. H. Talbot, The Anglo-Saxon Missionaries in Germany (London, 1954), pp. 205-26].

197 Plummer, Bede, 2, notes to Hist. ecc., v, cap. 19, p. 322.

19 F. Prinz, 'Heiligenkult und Adelsherrschaft ịm Spiegel merowingischer Hagiographie', $H Z$, 204 (1967), pp. 529-44.

so Vita Leobae, cap. Io, p. 126.

${ }^{31}$ Ibid., cap. 1, p. 122. 


\section{JANET L. NELSON}

thread and it was still coming out of her mouth, she rolled it round and round and made it into a ball.

Wanting to know what the dream meant, Leoba, anonymously, through an intermediary, asked an old nun who 'was known to have the spirit of prophecy'. This was the interpretation:

The thread coming out of her mouth is the teaching of wisdom proceeding from her heart through the ministry of her voice... The ball ... signifies the mystery of divine teaching which is set rolling through the mouth and the action of those who preach. ${ }^{52}$

It may be tempting to link this vision with Leoba's own conception of her religious role. Leoba may indeed have seen herself, above all, as a teacher. She had therefore to speak. Leoba's vision of the thread coming forth from her mouth authenticated, perhaps for the woman herself, the exegesis she offered and the counsel she gave. Yet the scope of her teaching was clearly bounded by convent and court; and it was Leoba's association with Boniface, and the presence of her body at Fulda, that gave her posthumous celebrity and caused her Vita to be written by a Fulda monk.

In this Vita, there is not just an emphasis on speech, but a use of direct speech in the form of lively dialogue. In the Lives of women saints, direct speech crops up very frequently: the saint speaks with her mother, her sister, her husband, her suitor, her spiritual advisor, and then (since she rypically ends up in a convent) with her abbess and her nuns; and she speaks both in 'real life', and in visions, with devils, or angels. It is significant that such articulate women could be depicted for a milieu and where the stereorype of feminine silence already had a secure place. But here genre has triumphed over gender: direct speech and lively dialogue are characteristic of Vitae.

Not Vitae, but Memorial Books record early medieval routinizations of charisma. It is unsurprising that few such texts survive from convents, small-scale and ephemeral as many women's houses clearly were. A few convents functioned in relatively extensive and long-term ways as centres of lay piety. Karl Leyser has explored the condirions for this in the case of several tenth-century Saxon convents. ${ }^{53}$ But there are few parallels elsewhere. Remiremont, in the Vosges, was refounded and reformed in 820 to

52 Ibid., cap. 8, p. 125.

33 Leyser, Rule and Conflict, cap. 6. 


\section{Women and the Word}

house eighty-four nuns. In the ninth century the house received royal patronage and royal visits. Thereafter its existence is documented no longer in annalistic sources but in its Memorial Book. ${ }^{54}$ Fifty-eight different hands have been identified. That is, fifty-eight writers, some of them nuns, were responsible between them, mainly during the ninth century, for entering I I, 500 names of those utriusque sexus for whom the nuns were to pray and the canons attached to the convent were to say Masses. Nor are these the names only of the noble kin of the convent's inmates: some are those of peasants who sought the nuns' patronage in death as in life. Through the written word-the 'Book of Life' itself-and through the spoken or chanted words of prayer, the religious women of Remiremont served their patrons and their clients. It is worth stressing, however, that Remiremont after the ninth century had no more than local importance, and that the late Carolingian monastic reform movement saw practically no new foundations for women in this part of the world..$^{55}$

The Miracle Book of the convent of St Walpurgis at Monheim, in Bavaria, offers another chance to catch an echo of women's voices. ${ }^{56} \mathrm{Made}$ during the 890 s, the collection gives details of 78 miracles, including 54 cures. The author's informants were the nuns, who supplied both written and oral testimony, and, with such posts as procuratrix and custrix, looked after the pilgrims who came to Monheim from an area of south-eastern Germany approximately 80 kilometres across. The nuns devised their own liturgical forms to cope with them: priests are very rarely mentioned in this book. It was the abbess herself-the materfamilias-who said blessings over the pilgrims. The author's identity and purpose account for the Monheim book's curiously sympathetic evocation of this woman's words: the priest Wolfhard wrote for the bishop of Eichstätt, lord and protector of Monheim, and its abbess. Author and patron alike had an obvious interest in developing the attractive power of Walpurgis's relics. Perhaps Wolfhard did his work all too well: it had no sequel, nor, as a result, can the history of Monheim be traced into the tenth century.

34 Liber Memorialis of Remiremont, ed. E. Hlawirschka, K. Schmid, and G. Tellenbach, $M G H$. Libri memoriales, 1 (Dublin-Zurich, 1970). The details below are taken from the Introduction. See further the review article of G. Constable in Speculum, 47 (1972), pp. 261-77.

ss For a rare exception, see R. H. Bautier, ed., Les Origines de l'Abbaye de Bouxières-aux-Dames au Diocèse de Toul (Nancy, 1987). The Oxford D. Phil. dissertation of J. B. W. Nighringale, Monasteries and their patrons in the Dioceses of Trier, Metz and Toul, 850-1000 (1988), throws new light on the networks of local aristocratic patronage around this and other houses.

s6 A. Bauch, ed, Ein bayerisches Mirakelbuch aus der Karolingerzeit. Die Monheimer Walpurgis-Wunder des Priesters Wolfhard (Regensburg, 1979). For what follows, see J. L. Nelson, 'Les femmes et l'évangelisation', Revue du Nord, 68 (1986), pp. 471-85, at pp. 479-80. 
In another contemporary miracle collection, that of Fleury, written in the 870 , occurs the following story:

When the relics of SS. Denis and Sebastian reached the monastery, and were about to be taken inside the church, a crowd of women who had been following the relic procession, and who were forbidden entry within the monastic precinct, asked to be allowed in to pray. When the monks refused, the womens' protest hardened (illis in prece perdurantibus) and they made such a row (tantus rumor) that some nobles arrived to persuade the abbot to allow the relics to be placed for a certain period in a tent outside the monastery gate. ${ }^{57}$

It was a small concession; and this story too has no sequel. The ecclesiastical hearing accorded these women's words, though not wholly unresponsive, is on the grudging side. The main function of miracle collections was to confirm the authority of the abbots and bishops who ultimately controlled relics. Churchmen were happy to record female participation in blessings and cures: but the women in these stories are essentially passive (if sometimes vocal) recipients of the ministrations and protection of men.

A little, mainly indirect, evidence suggests the existence of more active roles in early medieval convents. Every convent was meant to have its magistra; and girls (and sometimes boys too) were given basic religious instruction, including reading and writing, even though hagiographic texts more of ten refer to the imparting of textile skills to girls. ${ }^{58}$ The interests of lay patrons, and the acquiescence of male kin in girls' abductions from convents (marriage strategies had always to retain a certain flexibility), ensured that some beneficiaries of education by magistrae ended up presiding over secular households. But here, as so often, we are talking only about aristocratic women. Unfortunately there is very little evidence about godmothers, for that might tell something of humbler social levels than the highborn. J. H. Lynch's recent study has shown godparental responsibilities to have been an invention of the early Church which was effectively re-invented in the Carolingian period. ${ }^{59}$ From then onwards, not only do liturgical books show the godmothers, along with godfathers, at the baptism service, actually given a voice of their own in church, answering: Volo ('I wish it') to the question: Vis baptizari? ('Do you wish to be baptized?') on behalf of their godchildren;

${ }^{37}$ Adrevald, Miracula S. Benedicti, cap. 28, PL 124, col. 933.

${ }^{38} \mathrm{~S}$. Wemple, Women in Frankish Society, Pp. $175-8 \mathrm{I}$.

99 J. H. Lynch, Godparents and Kinship in Early Medieval Europe (Princeton, 1986), part IV. 


\section{Women and the Word}

but copies of the Lord's Prayer and the Creed survive in the Germanic vernacular, as well as Latin, with the injunction that they be taught to godchildren. The basic requirement of godparents-significantly the stress is laid equally on godmother and godfather alike-was that they know these texts, and through them teach their godchildren the Faith. Priests were supposed to hammer home the message with a series of questions for godparents to respond to in the confessional. However little we know of what godmothers (or indeed godfathers) actually did in the earlier Middle Ages, we can be sure that theirs was a form of teaching of which churchmen approved.

There was a still more basic teaching role for women. The Carolingian Church's views on Christian marriage entailed a revaluation of parenthood, including motherhood. 'Married couples must know', declared Jonas of Orleans, 'that in their own households they exercise a pastoral office'. ${ }^{60}$ Dhuoda we've already met as a confident author. What she wrote was a handbook of guidance for her fifteen-year-old son, William.

The words [or could we translate sermo by 'sermon'?] come from me: it's up to you to carry them out.... I am taking a very great deal of trouble, $O$ William my son, to send you words that will be the saving of you (verba salutis).... However many other books you acquire, I hope you will always want to keep reading this little book l've written for you. ${ }^{61}$

Though Jonas directed his advice to couples, Dhuoda was left by her husband's long absences to shoulder this parental responsibility alone. Her lonely situation was probably not exceptional for her time and class. Was she unique in her maternal concern to teach? Rosamond McKitterick argues persuasively, from the indirect evidence of women's bookownership and literary patronage, that she was not. ${ }^{62}$ Dhuoda's contemporary Osburh, wife of King Athelwulf of Wessex, did not write, but she did teach, with the help of her own words and a book of Saxon songs. Alfred ensured his mother's eternal fame as inspirer of his own boyhood efforts:

'Will you really give the book to whichever of us brothers can learn it fastest and read it aloud to you?' And she answered with a smile, rejoicing and affirming: 'Yes I will'. ${ }^{63}$

\footnotetext{
${ }^{60}$ Jonas of Orleans, De institutione laicali, ii, cap. I6, PL 106, col. 197.

${ }^{61}$ Dhuoda, Manuel, p. 70 (here Dhuoda goes on to quote St Paul) and pp. 80, 82.

${ }^{62}$ The Carolingians and the Written Word (Cambridge, 1989), pp. $211-27$.

${ }^{63}$ Asser, De rebus gestis Alfredi, ed. W. Stevenson (Oxford, 1904), cap. 23, p. 20.
} 
Arridens et gaudens atque affirmans: wouldn't every mother (and most teachers) like to be remembered like that!

The educational role of noblewomen extended beyond their own offspring to all their dependants. The Council of Meaux-Paris insisted that 'noble men, and especially noblewomen' (maxime potentes feminae) should take responsibility for the moral standards and basic religious instruction of all in their households: 'they must compel everyone to learn the Lord's Prayer and the Creed and say them often (tenere et frequentare)'. Parish priests, the canon continued, could deal with humble persons. ${ }^{64}$ The implication was that priests would find it difficult to deal with the denizens of aristocratic households-but that there precisely lay the job of potentes feminae. These women surely had an effect on the religious experience of humble persons too. Some, especially as widows, set up what were in effect house-convents in their own homes, reproducing one of the key growth-areas of the early Church. ${ }^{65}$ Ninth-century bishops, like their fourth-century predecessors, worried about supervising them.

To catch an echo of a potens femina at work we can move outside the domestic setting, and back to the sixth century. Gregory of Tours recounted the action of a matrona who, having patronized the holy man Lupicinus during his lifetime, felt she had a right to bury his dead body, and so establish his cult, on her own estate. Against the counterclaims of local peasants, she argued 'with forceful words', eventually put them to flight with her band of armed men, and carted off the Saint - who thereafter showed himself entirely satisfied with the outcome by performing miracles at his tomb. ${ }^{66}$ Strenuous matrons were in a position, when necessary, to lend the Word a little reinforcement. In this case, Gregory evidently approved. In mundane terms, though, the main beneficiary was the matron who controlled the cult-site. Again, the 'forcefulness' of nobility compensated for the weakness of gender.

There are a dozen or so manuscripts of Gregory's Vita Patrum. But there are sixty-five manuscripts of a work in which a sort of reverse image of that matron is to be found: the Life of St Gangulf. ${ }^{67}$ Written up in the late ninth century at Varennes, near Metz, this purports to record the fate of a seventh-century Frankish nobleman, whose virtuous life came to an

o4 C. 77, MGH. Concilia, III, ed. W. Hartmann (Hanover, 1984), p. I 24.

65 P. Brown, The Body and Society, pp. 263-5.

os Gregory of Tours, Liber Vitae Patrum, ed. B. Krusch, MCH. SRM, 1, ii, de Sancto Lupicino, Pp. 266-7 [trans. E. James, The Life of the Fathers (Liverpool, 1985), p. 97].

67 Vita Gangulfi, cap. I 3, ed. B. Krusch and W. Levison, MGH. SRM, VII, PP. 142-70, at Pp. I66-7. For the Vita's date, see Krusch's comments at P. I4S. 
abrupt halt when he was murdered by his wife's lover, the family chaplain. Soon after, a report came to the widow that crowds were coming to seek the miracles being worked at her late husband's tomb.

She replied: 'If he can work miracles, so can my arse'. As soon as this wicked statement had left her mouth, from the opposite end of her anatomy came an obscene sound. The day on which this happened was a Friday. And thereafter, for the rest of her life, whatever number of words she tried to emit on a Friday, from that other end of her body came the same number of shameful noises. To it, it is indeed true to say, the miracles of the man of God are not to be compared!

Hrotsvitha of Gandersheim, who produced a poetic version of the Vita Gangulfi said she did not like to tell this bit because it 'made her little tongue so ashamed'. (She told it just the same.) ${ }^{68} \mathrm{I}$ am telling it because I think it reveals something about the ambiguity of women's relationship to the word. Generations of monks and nuns must have laughed at it: the manuscripts of the Vita Gangulfi date from the tenth to the fifteenth century-and only one has a marginal note at chapter 13 : istud capitulum in publico non legatur. ${ }^{69}$ The diets of medieval religious made farting a chronic worry: the Rule of Benedict of Aniane has a special section about this problem. ${ }^{70}$ There was Schadenfreude to be enjoyed in the discomfiture of the wicked woman who misused her voice, bringing forth foulness instead of truth and paying a lifelong penalty in public shame.

But this story, in all its crudeness, may also be gender-specific: not in its depiction of a female sceptic, but in its complete negation of the female voice. It suggests that women as exponents of the word operated under particular constraints, and that attitudes to their 'noise' were peculiarly ambiguous. We have heard Asser on the queen as mother and teacher: his only other piece of dialogue involved another woman, this time a wicked queen who, like Gangulfs wife, demonstrated and confirmed her own ruin by bad words. After murdering her husband, the King of Wessex (admittedly by mistake-she had intended to kill his young favourite), Eadburh fetched up 'offering many rich gifts' at the court of Charlemagne, who asked her whom she would rather have, him or his

${ }_{68}$ Hrotsvitha, Passio Sancti Gongolfi Martiris, lines 563-82, Opera, pp. 50-I. See Dronke, Women Writers, p. 61 , for a stylish translation of this passage.

69 Vita Gangulfi, p. 166, at note *".

70 C. 32 , ed. J. Semmler, in Corpus Consuetudinum Monasticarum, 1 (Siegburg, 1963). pp. \$24-5. For la grande bourre as a consequence of ninth-century monastic diets, see M. Rouche, 'La faim i l'époque carolingienne', $R H, 250$ (1973), pp. 295-320, at p. 317. 
son. Eadburh, perhaps forgivably, but in Asser's view 'stupidly, without thinking', said: 'I choose your son, because he's younger than you'-and, of course, ended up with neither. ${ }^{71}$

How do we explain this disparagement of the words of women? It won't quite do to invoke a general context of Christian misogyny: as we've seen, other evidence from the earlier Middle Ages indicates that some forms of feminine access to the Word, and to the word, were relatively unproblematic. It may well be that in this period male religious found other categories 'good to think': that is to say, found ways other than gender to demarcate pure from impure, permitted from forbidden, tamed from wild. ${ }^{72}$ But there is one specific reason for churchmen's persisting anxiety about women's words in societies only recently and partially converted to Christianity, and that is the association of women with the words of paganism. Non-Christian magic was widely practised by women in the earlier Middle Ages-or at least learned churchmen believed that to be so. Burchard of Worms in the early eleventh century enjoined priests to ask female penitents: Fecisti quod quaedam mulieres facere solent ...? ("Have you done what certain women are in the habit of doing ...?') ${ }^{73}$ A number of the outlawed practices involved the saying of spellsincantationes - to invoke fertility of various kinds. ${ }^{74}$ Asser may hint at something of the kind in mentioning the presence of women at the wedding-feast, when Alfred was struck down by what many suspected was fascinatio - the casting of a spell..$^{75}$ Einhard, in his account of the miracles worked by the translated relics of SS. Petrus and Marcellinus, pitted these Christian wonder-workers against the incantations of mulierculae guilty of 'vain and presumptuous superstition'.76

'From the Montanist movement onwards', wrote Ronald Knox in I950, 'the history of [Christian] enthusiasm is largely a history of female emancipation, and it is not a reassuring one'. ${ }^{77}$ Some early medieval people

71 Asser, De rebus gestis Elfredi, cap. I 5, pp. 13-14. (The story continues: 'Dedit tamen illi unum magnum sanctimonialium monasterium....)

72 Cf. I. Wood, 'Christians and pagans in ninth-century Scandinavia', in B. Sawyer, P. Sawyer, and I. Wood, eds, The Christianization of Scandinavia (Alingsas, 1987), pp. 36-67, at pp. 64-7.

${ }^{73}$ H. J. Schmiz, Die Bussbucher und das kanonische Bussverfahren, 2 vols (Düsseldorf, 1898), P. 45 I-2.

74 C. Vogel, 'Pratiques superstitieuses au début du XIe siècle d'après le Corrector sive Medicus de Burchard', Études de civilisation mediévale LXe-XIle siècle. Mélanges offerts à E.-R. Labande (Poitiers, 1974), pp. 751-61.

75 Asser, De rebus gestis Alfredi, cap. 74, pp. 54-5.

${ }^{76}$ Einhard, Translatio SS. Marcellini et Petri, PL 104, cols 567-8.

${ }^{77}$ R. Knox, Enthusiasm. A Chapter in the History of Religion (Oxford, 1950), cited in I. N. Lewis, Ecstatic Religion (Harmondsworth, 1971), p. 3 I. 


\section{Women and the Word}

(without worrying too much about female emancipation) did find reassurance in the story of St Opportune (still one of the most popular saints in Normandy): when she was assailed by the devil, that fortis bellatrix, given confidence by prophetic visions of women saints, shouted out: 'You got Eve, but you won't get me!'78 Though demons as often spoke through men as through women in the earlier Middle Ages, prophecy did tend to be a female speciality: and it could, in certain forms, be given churchmen's approval as an official medium. ${ }^{79}$ Gregory of Tours confronted several varieties. Of three cases in the Histories, one he condemned as a false prophet, mouthpiece of the devil; a second he thought genuinely possessed of a gift of prophecy, but through an 'unclean spirit'; a third was divinely inspired. ${ }^{80}$ The soothsayers of whom Gregory disapproved were not enthusiasts, but women doing a job, and making money at it. They worked with predictions as some other women worked with incantations. The sixth-century Life of St Genevieve offers an example of a prophetic gift that was almost fatally misconstrued. When Atrila the Hun besieged Paris, and the citizens planned to take their valuables for safekeeping elsewhere, Genevieve 'summoned the citizens' wives (matronas) and persuaded them to devote themselves instead to fasts and prayers, following the examples of Judith and Esther'. The women agreed. But when Genevieve tried to persuade the husbands not to take their goods out of the city, 'the citizens rose up against her saying: a pseudoprophet has arisen in our times'. A meeting to decide whether to kill her by stoning or drowning was interrupted only by the timely arrival of an archdeacon from Auxerre, who vouched for Genevieve's holy credentials. ${ }^{81}$

With this story, we can contrast the ninth-century case of Thiota-

a pseudoprophetess, who claimed to know the precise date of the end of the world, and other things which God alone knows, as if they had been divinely revealed to her.... As a result many humble persons,

78 Vita et miracula S. Opportunae, ActaSS, April. III, pp. 61-72, at cc. 3 and 21 , pp. 63, 67. This Vita was written $c .890$ by Bishop Adalhelm of Sées.

79 Compare M. Warner, Joan of Arc. The Image of Female Heroism (London, 1981), pp. 86-95; Brown, The Body and Society, pp. I so-I.

80 Libri Historiarum, V, cap. I4, p. 210 ; VII, cap. 44, pp. 364-5; VIII, cap. 33, pp. 40I-2.

81 Vita Genovefae, cc. 12-13, ed. B. Krusch, MGH. SRM, III, Pp. $219-20$. (For the biblical male 'pseudoprophet', see Acts 13.6 ; cf. Matt. 24. 11 , 23.) The most recent discussion of the Vita's date is by I. N. Wood, 'Forgery in Merovingian hagiography', in Fälschungen im Mittelalter, MGH. SRI, 33. pt V (Hanover, 1988), pp. 369-84, at pp. 376-9. Wood plausibly suggests a sixth-century, rather than fifth-century, date, but rightly adds that a non-monastic female saint is an oddity at any date in the early Middle Ages. 


\section{JANET L. NELSON}

men and women, came to her with presents and asked her to pray for them. Still more serious, certain priests became her followers, believing her to be their magistra sent by God.

Haled before bishops, Thiota confessed that she had been taught her 'prophecies' by a certain priest, and that her own motive had been a quest for material gain. She was flogged in public, and

ignominiously deprived of the office of preaching (officium praedicationis) which she had assumed unreasonably (inrationabiliter) and presumed to exercise against the usage of the Church (contra morem ecclesiasticum )... and so she put an end to her prophesyings. .. ${ }^{82}$

This story has been read as evidence for the repressive attitudes of the Carolingian Church towards 'women aspiring to spiritual leadership or pastoral care' who also 'chose to remain in the world', and as a 'notorious instance in which women's public roles and power within the Church were condemned' ${ }^{83}$ But Thiota was not condemned as 'an irrational woman', nor for preaching as such. There is an implied misuse of what could have been done rationabiliter. Thiota's preaching was said to have been, not against lex or auctoritas - but against mos: custom, or usage. Though custom mattered, it did not always have the last word, since truth might override it. The role of magistra was not disapproved per se: it was denounced in this case because the teaching was false, and done from base motives. Thiota's words were totally devalued when they turned out to have been dictated not by the Holy Spirit but by a bad man. There is a notable contrast between the annalist's account of Thiota's misconduct and his notice, in the very next annal (the juxtaposition can hardly be coincidental), of the condemnation of Gottschalk 'who was said to be a heretic'. The annalist betrays a sneaking sympathy for Gottschalk's views by hinting that some thought him to have been convicted inrationabiliter. Far from seeking to diminish Gottschalk by imputing moral failings, the annalist takes him and his teachings seriously. ${ }^{84}$

What difference did gender make? It has been said that women were confined to the 'private' sphere, while men operated in the public one. In the earlier Middle Ages this distinction is not entirely apt. Court and convent were both in a sense public spaces. But women as such lacked

${ }_{82}$ Annales Fuldenses, sa 848, ed. F. Kurze, MGH, SRG, (Hanover, 1891), pp. 36-7.

${ }^{83}$ Wemple, Women in Frankish Sociery, p. 145 ; Schulenburg, 'Female sanctity', p. 116.

${ }^{84}$ Annales Fuldenses, sa 848 , p. 38. On this case, see D. E. Nineham, 'Gottschalk of Orbais', JEH, 40 (1989), Pp. I-I 8. 


\section{Women and the Word}

autonomy: they were shown as being directed, for good or ill, by men. Genevieve was vouched for by a sound masculine authority-figure; Thiota led astray by a false one. Certain women, in certain contexts, were encouraged, posthumously and perhaps also in their own liferimes, to speak up; but beyond them we glimpse other beneficiaries, individual or collective, who were always male; in Leoba's case, the monastery of Fulda; in St Opportune's, the bishopric of Sées; in that of St Walpurgis at Monheim, the see of Eichstätt. Endowed with direct speech in the hagiographic record, women more often requested and responded than asserted. Men located and authorized, prescribed and transcribed, the utterances of these women.

In two cases known to me, the women's words recorded by churchmen sound like direct expressions of the women's own feelings. In the first case, a woman, Agintrude, involved in a lawsuit against a priest, protested in court that witnesses who might otherwise have supported her had been dererred 'through fear of the priest'. ${ }^{85}$ In the second, Queen Theutberga, brought under very strong pressure to incriminate herself on a charge of sodomite incest, so that her husband, King Lothar II, could repudiate her, was asked by a team of Lothar's bishops to state frankly whether she had confessed of her own free will or under compulsion. 'She gave us this answer', so runs the bishops' report, 'with a bitter look (aspero intuitu): “Do you think I'd have wanted to destroy myself thus for anything in the world? I have confessed. All I beg of you, for the love of God, is that you will now grant me mercy... ${ }^{n 8}$ In both these cases, we seem to hear the voices of women placed by their gender quite literally at the mercy of powerful men. And yet, for all the pressure they were under, these women spoke out, and their thoughts have come down to us in their own words.

For churchmen, the words of women, whether in fact or in fiction, remained, as they have remained, literally equivocal. The reception of women's words was always uncertain. The author of the Life of Gangulf, and, less blatantly, the writer of the Fulda Annals, were already expert in the tactics used a thousand years later by Dr Johnson: 'Sir, a woman's preaching is like a dog's walking on his hinder legs. It's not done well; but you are surprised to find it done at all'. More disparaging than being sent back to the loom, more debilitating than being silenced, was to be derided. Spoken words, anyway, are ephemeral. The passage of time stilled not only the voice of the exceptional individual who, while she lived, had

${ }^{85}$ Nelson, 'Dispute settlement', pp. 56-9, 248-50.

${ }^{86}$ MGH. Cap, II, no 306, p. 467. 
counselled king or magnate, but also the institutional voices of women's religious houses. What happened to Whitby? To Chelles? To Remiremont? To Vézelay? ${ }^{87}$ If they did not disappear completely, they lapsed for centuries, sometimes permanently, into mere local existence, with merely local patrons. For many female communities, no long-term institutionalization occurred-nor perhaps was it attempted.

A glance forward to the twelfth century shows a world in which some of the details differed, but the basic rules of gender were the same. If changes in inheritance customs at the level of kingdom and principality had given a few women the chance to speak out about their own preferences, ${ }^{88}$ the options were still determined by men. Within the professional Church, Southern's new organization-men were unenthusiastic about feminine charisma, and more anxious than ever to keep the line of gender firmly drawn, because it strengthened the line between clergy and lay. An eleventh-century Mary Magdalene as depicted by the monks of Vézelay recalled, on arrival in France, that it was not permitted for women to preach, and therefore left that job to her brother Lazarus, ad peragendum illus operum idoneus. ${ }^{89}$ True, in some parts of twelfth-century southern France, there were stories depicting Mary and, still more strikingly, the sancta virago Martha, as local preachers so persuasive that 'hardly anyone went home from their preaching an unbeliever ${ }^{.90}$ But the French mission of Mary and Martha belonged to the remote and heroic (and mythical) past. When real live women attempted to imitate these female apostles, they were met with the familiar weapon of derision. In clerical reactions to the Waldensians, professional jealousy waxed most vitriolic against sisters who preached. These women were not masterful ladies, and they had no fixed address. ${ }^{91}$ Even at élite level, there was now a chasm between teaching in the home (including the court), conducted in part by women, and the all-male world of the schools. Nothing in a curriculum based on the learning of Late Antiquity held out prospects for

87 For Vézelay's ninth-century fate, see Nelson, 'Commentary', lagainst Schulenburg, 'Women's monastic communities', p. 28 I, n. 49:'destroyed by the Vikings']. Cf. J. Martindale, 'The nun lmmena and the foundation of the Abbey of Beaulieu: a woman's prospects in the Carolingian Church', above, pp. 27-42.

$88 \mathrm{~J}$. B. Gillingham, 'Love, marriage and politics in the twelfth century', Modern Language Studies, 25 (1989), pp. 292-303.

89 Sermo de Sancta Maria Magdalenae, ed. B. de Gaiffier, 'Hagiographie bourguignonne', AnBoll, 69 (1951), pp. I 31-47, at p. 146. See Lifshiz, 'Femmes missionaires', pp. 20-I.

90 Vita B. Mariae Magdalenae et sororis eius S. Marthae, falsely attributed to Hrabanus Maurus, $P L$ 112 , col. 1496.

$91 \mathrm{G}$. Gonnet, 'Le chéminement des vaudois vers le schisme et l'hérésic (1 174-1218)', Cahiers de Civilisation Médiévale (1976), pp. 309-45, at pp. 311, 315, 317-18. 


\section{Women and the Word}

women to participate on equal terms with men, indeed, on any terms at all.

The twelfth-century experience throws light retrospectively on the earlier Middle Ages. It reveals women firmly located in settings-great households, ecclesiastical power-structures-where control by men was effectively guaranteed. Yet it also highlights the forms of early medieval female activity that, yes, were permitted because in the interests of maledominated institutions, but nevertheless allowed some women a kind of autonomy later denied them. The fault-lines of the earlier Middle Ages did not follow the public/private distinction that some modern historians allege to have been as universal, as timeless, as commonsensical, as patriarchy. ${ }^{92}$ In the earlier Middle Ages, the power of royal and noble dynasties was still precarious. It was a world of inspired improvisations, of structures in the making, of ethnogenesis, and, as of ten, of ethnoabortion. The frequency with which royal and noblewomen were abducted indicates their importance as transmitters of status. The dynastic positions acquired by women meant that their words could command a hearing. Class sometimes transcended gender.

The Carolingian Church, dependent on royal and noble power for such security as it could get, offered certain opportunities for earlier medieval women to speak out. It was a missionary church, not so much in the sense that it preached to the heathen without (and the relatively small endeavour on this front offered in any case little scope for women's participation ${ }^{93}$ ), as in its determined effort to convert the nominally Christian people within. The Christianization of kingship and war were the tip of the iceberg: to touch nine-tenths of human experience, the Church needed to gain access to the household, where pre-Christian, or non-Christian rituals still held their own: where naming-practices, for instance, had hardly been touched by Christianity. ${ }^{94}$ Only by recruiting women's teaching-power, by licensing their words, could the Church permeate social practice with the teaching of the Word. With some hesitation, and many qualifications, the licence was granted. But the disabilities of gender were only masked, not changed. The Gregorian Reform in etching more sharply the line dividing clerical from lay also

92 See J. L. Nelson, 'The problematic in the private', Social History (1990) pp. $355-64$.

93 As observed by Lifshitz, 'Les femmes missionaires'.

94 Nelson, 'Les femmes', p. 473; J. Verdon, 'La femme vers le milieu du IXe siècle d'après le polypryque de l'abbaye de Saint-Rémi de Reims', Mémoires de la Société d'Agriculture, Commerce, Sciences et Arts du département de la Marne, 91 (1976), pp. I I I-34, at pp. I 1 7-27; H.-W. Goctz, Leben im Mittelalter (Munich, 1986), pp. 37-8. 
reaffirmed the line of gender. At the same time, the clerical professionalization of writing and teaching made magistrae bad to think. Yet the reformers' programme could never have been formulated without the support of laymen; and that in turn presupposed a measure of success for those women who had helped implement the Carolingian Reforms in the households, and the hearts, of the laity. The eleventh-century reformation of the clerks hardly entailed une restauration de la femme - but it rested on the work, and the words, of women as well as men.

In 1970 , it was exceptional for Southern to assign women even twenty pages of Western Society and the Church. In 1977, the Ecclesiastical History Society was in the avant-garde when-despite qualms as to the project's commercial viability-it devored its first volume of Subsidia to Medieval Women. In 1989-90 the Society is devoting its conferences to The Church and Women (and no one doubts that $\mathrm{SCH} 27$ will sell). It is timely to end on a note of celebration. As our new President reminds us, the Society has always been distinguished by the warm welcome it gave to women. By their contributions-secretarial, organizational, editorial, presidential, and (last but not least) verbal-to the Society's life and work, the women have made an ample return.

King's College London 